Check for updates

The BMJ

Cite this as: BMJ 2021;373:n979 http://dx.doi.org/10.1136/bmj.n979 Published: 15 April 2021

\title{
Covid-19: Single dose of Pfizer or AstraZeneca vaccine produces strong antibody response in over $80 \mathrm{~s}$
}

\section{Elisabeth Mahase}

A single dose of the Pfizer or Oxford-AstraZeneca covid-19 vaccine produces equivalent antibody responses five weeks after vaccination, a small study looking at people over 80 has found.

The study, led by University of Birmingham researchers and made available through a preprint, found that antibodies specific to the SARS-CoV-2 spike protein were present in most people in both groups $-93 \%$ after the Pfizer vaccine and $87 \%$ after the AstraZeneca vaccine. ${ }^{1}$

Researchers have said that these findings are "reassuring" for countries that decided to delay second doses in favour of vaccinating more people with a first dose. In the UK, people over 80 were in the first priority group for vaccination and received either the Pfizer or AstraZeneca vaccine. At the end of December 2020, the UK chief medical officers announced that the second doses of the covid vaccines should be given towards the end of 12 weeks rather than after the previously recommended 3-4 weeks. $^{2}$

The research team collected blood samples from 165 people aged 80 to 99 years and living independently 5-6 weeks after their first vaccine dose. Of these, 76 received the Pfizer vaccine and 89 received the AstraZeneca vaccine. They then used a range of assays to measure the immune response generated.

A small number of people (eight) had signs of previous natural covid-19 infection. Compared with those without previous infection, their antibody and $\mathrm{T}$ cell responses after the first vaccine dose were significantly higher (691-fold and fourfold, respectively). The study also found stronger $\mathrm{T}$ cell responses in people who had received the AstraZeneca vaccine, with $31 \%$ of this group producing detectable $\mathrm{T}$ cell responses compared with $12 \%$ of the Pfizer-BioNTech vaccine group.

Helen Parry, study author and National Institute for Health Research academic clinical lecturer at the University of Birmingham, said, "These antibody responses are very encouraging as they back up the strong real world data we are seeing in the UK. We now need to carry out further research to understand what this difference in $\mathrm{T}$ cell responses means and how we might work to optimise future vaccination strategies."

The researchers said that the clinical importance of the difference in $\mathrm{T}$ cell response was not yet clear, but it could be important when dealing with variants of covid-19. Paul Moss, co-author, principal investigator of the UK Coronavirus Immunology Consortium, and haematology professor at the University of Birmingham, said, “[T cells] can help to recognise different viral variants, they are somewhat less susceptible to loss of immune recognition against viral variants than antibody responses.

"The difference between antibodies and T cells is that antibodies are seeing shapes, like a lock and a key, and therefore a single amino acid can make a big change in the structure, and that means a lot of antibodies can't bind. Whereas T cells see little peptide fragments, the virus is stripped into fragments and therefore the $\mathrm{T}$ cell response is not so badly lost against single amino acid changes."

The research was supported by the UK-CIC and funded by UK Research and Innovation and National Institute for Health Research.

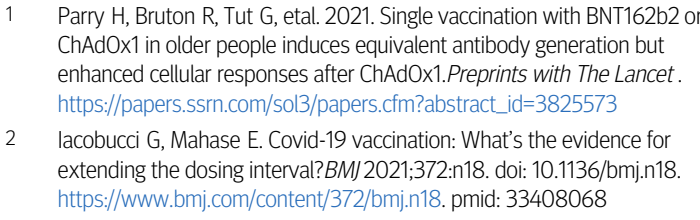

This article is made freely available for use in accordance with BMJ's website terms and conditions for the duration of the covid-19 pandemic or until otherwise determined by BMJ. You may use, download and print the article for any lawful, non-commercial purpose (including text and data mining) provided that all copyright notices and trade marks are retained. 